\title{
臨床報告＼cjkstart急性感染症に対する小柴胡去半夏 加括樓根湯の使用経験
}

岩崎勲

要旨 急性感染症に小柴胡去半夏加括樓根湯を使用し有効であった 3 例を報告した。症例は 急性肺炎と AGML を合併した例，胆管炎から敗血症を併発した例，水腎症に急性腎孟腎炎を 併発した例でいずれも小柴胡湯証を呈しながらも強い渴を示していた。抗生剂や輸液も併用し たが主要な効果は本方剤によると思われた。本方剂は小柴胡湯より半夏を抜き人参を 1.5 倍に 増量し括樓根を加えたものである。

小柴胡湯条文の中で本方剂に関連した部分について，先人たちの見解を検討した。

小柴胡去半夏加括樓根湯と金實要略の柴胡去半夏加括樓湯との異同について考察し，病態に 若干の差があることを見た。

キーワード：急性感染症，小柴胡湯証，渴，小柴胡去半夏加括樓根湯

\section{緒 言}

小柴胡湯が各種の感染症に頻用される事は衆知 のことである。小柴胡湯は少陽病の虚実間の薬方 であるが，加減方も多くありまた種々の方剂との 合方も用いられていて非常に応用範囲が広い。今 回，傷寒論に打汀る小柴胡湯条文方後にある加減 方のうちの一つを急性感染症に使用して有効な例 を経験した。そのうち臨木経過と検查成績との対 比が明瞭な 3 例を報告し，あわせて小柴胡湯条文 について若干の考察を加えた。

\section{方法と結果}

以下は傷寒論太陽病中篇にある小柴胡湯の主治 を論じた条文である。

『傷寒五六日中風, 往来寒熱, 胸脇苦満, 然然 不欲飲食, 心煩喜嘔, 或胸中煩而不嘔, 或渇, 或 腹中痛, 或脇下痁硬, 或心下悸, 小便不利, 或不 渴，身有微熱，或咳者，小柴胡湯主之。……(途
中省略）……若胸中煩而不嘔者, 去半夏人参, 加 括樓実一枚。若渴, 去半夏, 加人参合前成四而 半, 括樓根四両。若腹中痛者, ……(以下省略)』 上記の方後加減方のうちの「渴」の去加方に従っ $\tau$, 柴胡 7 , 黄芩 3 , 人参 4.5 , 大雷 $3, 甘$ 甘草 2 , 括樓根 4 , 生姜 4 の方剂を作り，これを仮に小柴 胡去半夏加括樓根湯と名つけた。

本方を小柴胡湯証があって嘔がなく渴が強い, を使用目標として上記分量で煎剤として投与し た。

次に症例を提示する。

症例 $1: 62$ 歳, 男

診 断：(1)急性肺炎, (2)AGML

既往歴：特記すべきことはないがアルコールを 常飲している。

現病歴： 悪寒発熱が出現した。 軽い上腹部痛, 嘔父, 全身倦怠, 拱食不能となり 来院。内視鏡検查で胃, 十二指腸に広沉 な AGMLが認められた。また胸部 XP で左中下 
野に広汎な肺炎像がみられた（写真 1 )。

現 症: 身長 $161 \mathrm{~cm}$, 体重 $51 \mathrm{~kg}$ 。顔色不良。球 結膜に貧血, 黄染なし。舌には白黄乾苔。脈浮弦 数。腹力やや軟だが腹直筋緊張 強い。心下癌鞕 $(+)$, 右胸脇苦満 $(+)$, 臍下不仁 $(+)$ 。渴 $(+)$, 口苦 $(+)$, 労作時呼吸困難 $(+)$, 乾咳 $(+)$, 嘔気 $(-)$, 食思不振で摂食不能, 尿不利 $(+)$ 。

経 過(図 1)：初診時 WBC $7000 / \mathrm{mm}^{3}$ (st 70 $\%, \operatorname{seg} 14 \%$ ), CRP $38 \mathrm{mg} / \mathrm{d} \ell, \mathrm{BSR} 117 \mathrm{~mm} / \mathrm{hr}$ で著 明な炎症反応がみられた。BUN $50 \mathrm{mg} / \mathrm{d} \ell, \mathrm{Cr} 2.6$ $\mathrm{mg} / \mathrm{d} \boldsymbol{\ell}$ 腎機能が低下していた。動脈血ガス分析 は $\mathrm{pH} 7.540, \mathrm{pCO}_{2} 27.0 \mathrm{mmHg}, \mathrm{pO}_{2} 59.8 \mathrm{mmHg}$ 。 往来寒熱, 尿不利, 渴などから当初柴苓湯エキス を投与した。胸部 XP の肺炎陰影はウイルス性を 強く疑わせたが念のため抗生剂 CPZを併用した。 輸液による栄養補給もした。しかし相変わらず発 熱, 自覚症状は改善せず WBC 14400/ $\mathrm{mm}^{3}$ （st 47 $\%$, seg $46 \%$ ), CRP $44 \mathrm{mg} / \mathrm{d} \ell$ と炎症反応は強度 のままである。再度症状を洗い直してみた。発熱 は往来寒熱であり潮熱ではない。汗はあまりな

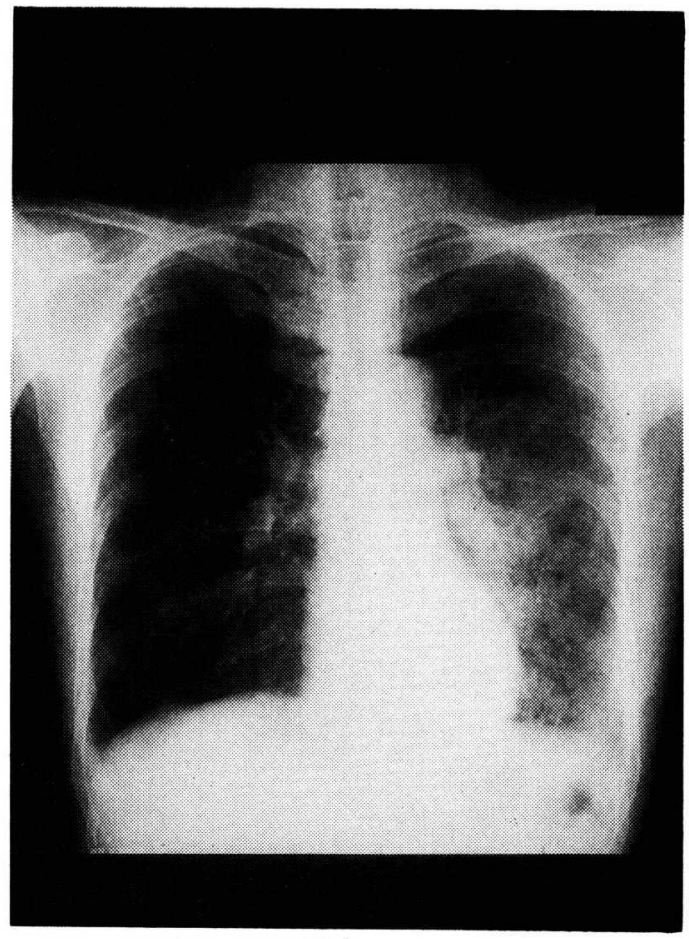

写真 1

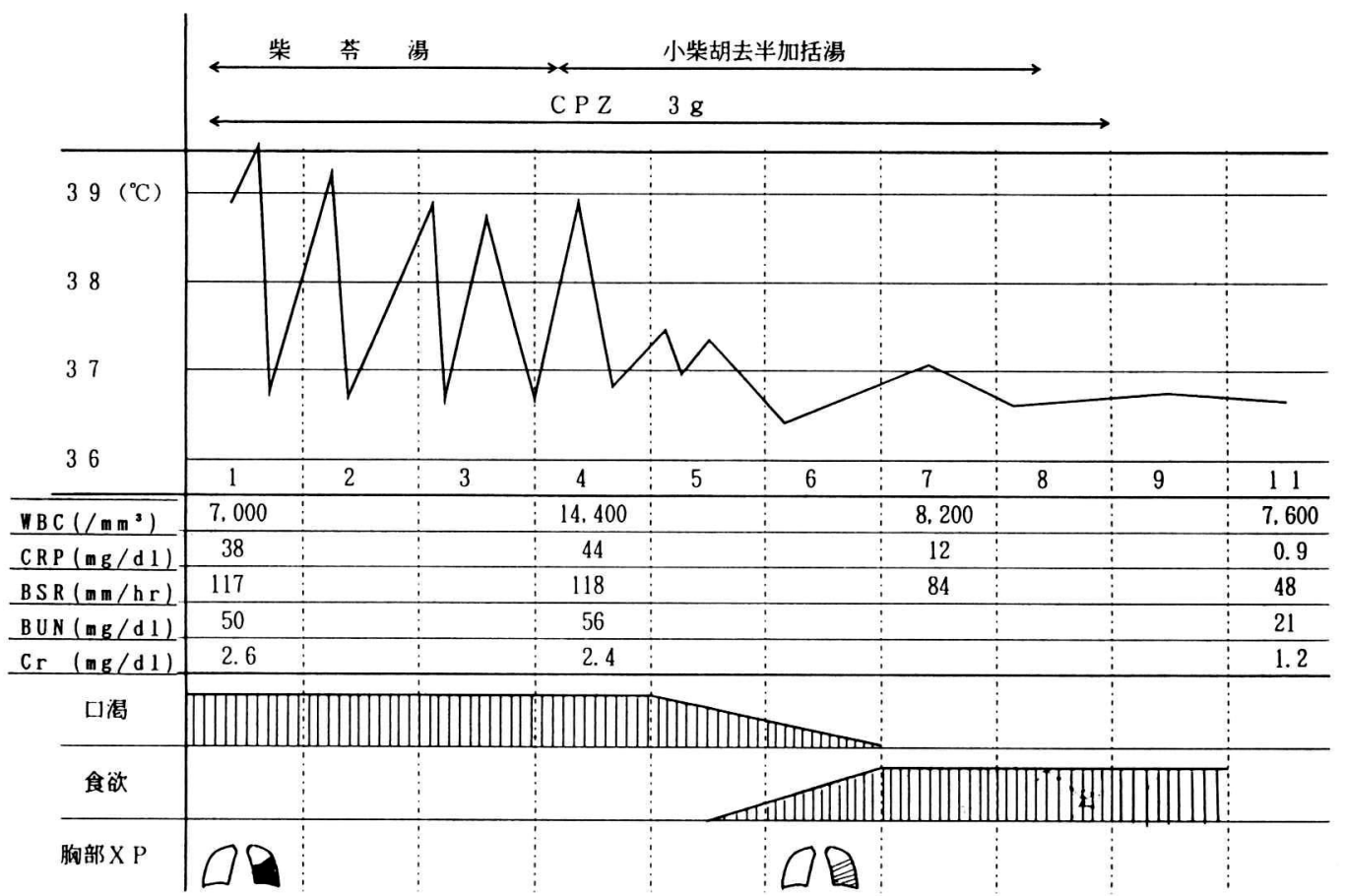

图 1 
い。口苦は強い。排便はないが腹満も苦痛もな い。胸脇苦満は相変わらず。倦㤐感は強い。尿不 利 $(+)$ 。渴については, 多飲を要するほどではな くロ乾に近い。会話もままならない程の乾きであ る。舌, 脈は同じ。これらからやはり少陽病に留 まっていて陽明期には入っていない。大柴胡湯ほ ど実してはいない。やはり小柴胡湯と思われた。 小柴胡湯の条文を見直してみると, 方後加減方に 渴の記載があることがわかり, 前述の小柴胡去半 夏加括樓根湯として投与してみた。結果はよく奏 功し, 翌日には解熱し三日後には自覚症状はほと んぞなくなり食事も普通にとれるよらになった。 但し検查では, 胸部 XP の肺炎像は大部分残存し 炎症反応も中等度残っていた。これらがほぼ正常 化したのは入院後11日目であった。

抗生剂も併用していたが病状の経過には影響な かったと思われる。

症例 $2: 73$ 歳, 男

診 断: 肝内胆管炎に伴う敗血症

既往歴：S63胆石，総胆管結石の手術 現病歴： 悪寒して $38^{\circ} \mathrm{C}$ 台の発熱

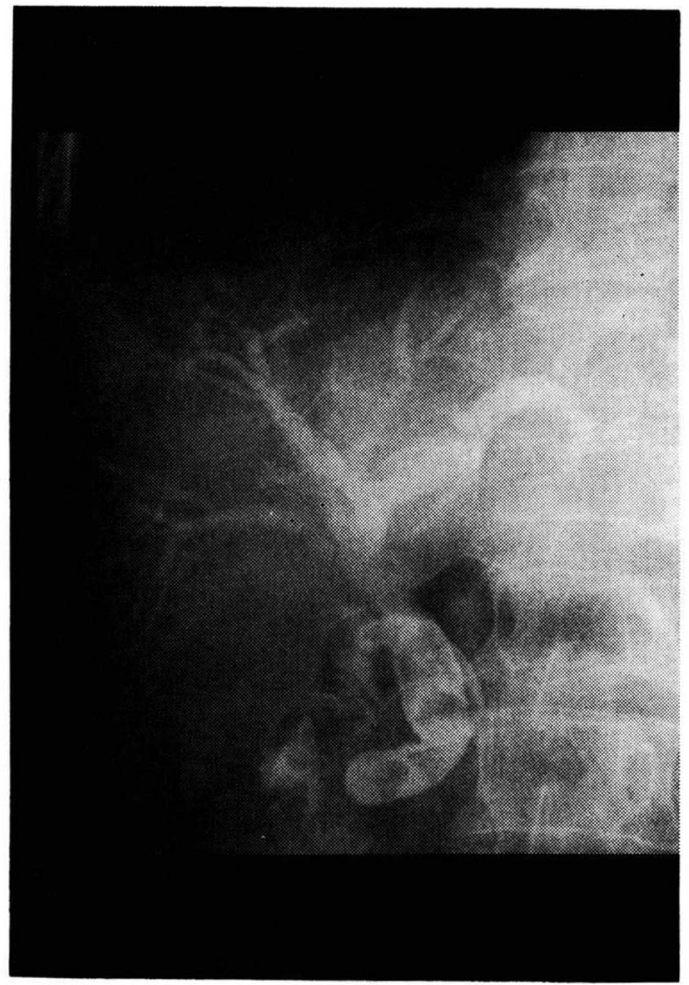

写真 2 あり。翌早朝より右季肋部痛, 嘔吐頻 回あり来

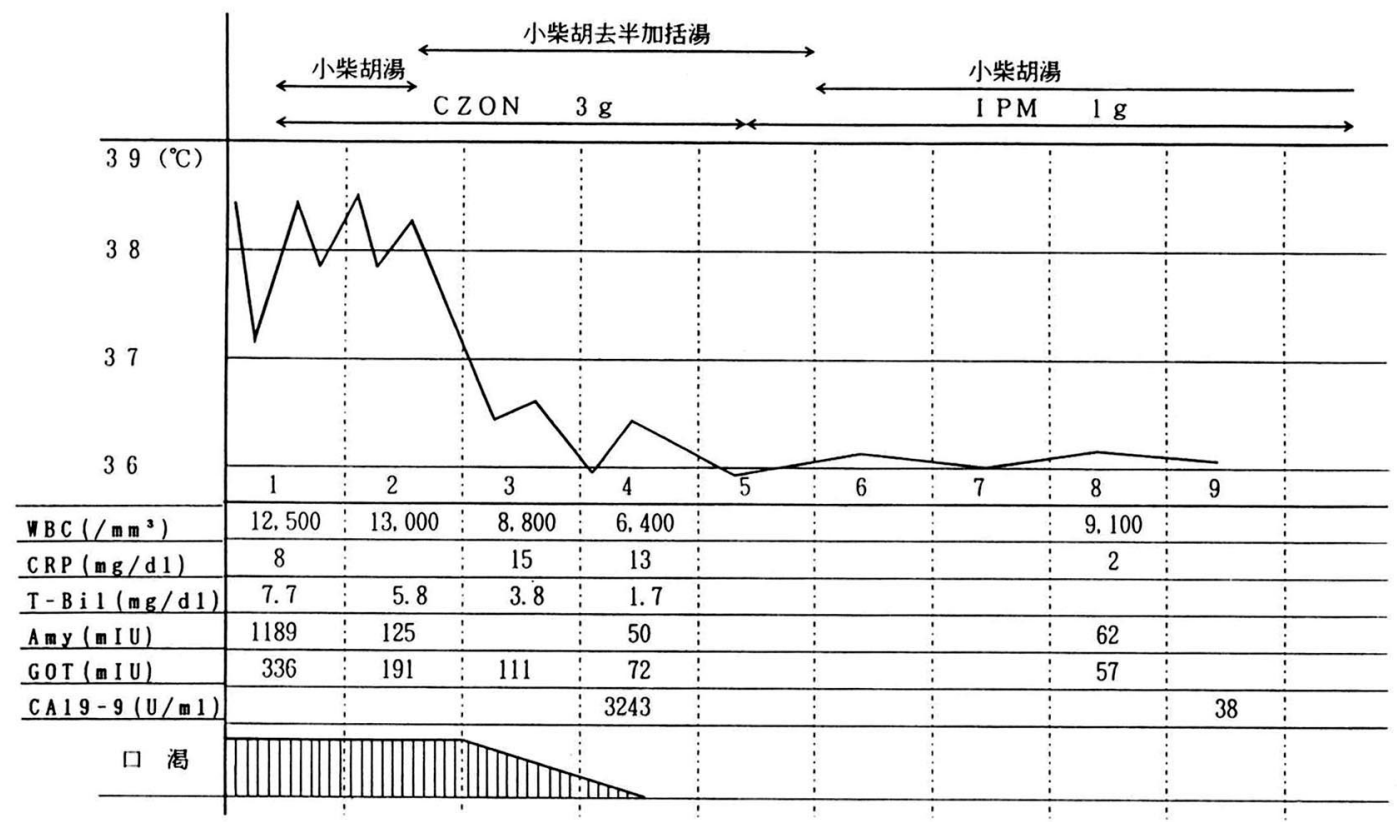

国 2 
院。超音波検査等で総胆管結石, 肝内胆管結石が 見出された（写真 2$) 。$

現 症: 球結膜に黄染あり。舌には白黄乾苔あ り。脈弦数。腹力軟。右胸脇苦満 $(+)$ 。心下痁鞭 $(+)$ 。往来寒熱, 口苦, 渴が著しい。脱力感も著 明。嘔気はなくなってきている。

経過(図 2): 初診時 $\mathrm{WBC} 12500 / \mathrm{mm}^{3}$ (st 37 $\%$, seg 57\%), CRP $8 \mathrm{mg} / \mathrm{d} \ell, \quad$ Alp $493 \mathrm{IU} / \mathrm{L}$, GOT $336 \mathrm{mIU}$, GPT $217 \mathrm{mIU}$, Amylase $1189 \mathrm{mIU}$, T. Bil $7.7 \mathrm{mg} / \mathrm{d} \ell$, 血液培養で後日 pseudomonas が検出された。CA19-9 は 3243U/m $\ell$ と高く強い 炎症がみられる。胆管炎による敗血症, 肝障害, 随伴性膵炎である。

治療は小柴胡湯エキス $10 \mathrm{~g}$, 抗生剂 $\mathrm{CZON}$, 絶 食にして IVH による輸液管理を行った。翌日も 変化なく渴（症例 1 と同様口乾に近い）が強度で あるため, 小柴胡去半夏加括樓根湯に変更した。 今回も奏功し, 急速に自覚症状が改善した。症例 1 と同じく他覚所見の改善には時間がかかってい る。抗生剂 CZON は pseudomonasには感受性が ないことがわかり，IPM に変更した。解熱効果 は抗生剂ではなく本方剂によるものと思われる。
症例 $3: 53$ 歳, 女

診 断：急性腎盂腎炎

既往歴：糖尿病で治療中。糖尿病性網膜症, 糖 尿病に伴ら両側の水腎症。H 3 年に腎血腎炎と敗 血症に罹患。

現病歴 : 頃より食欲不振, 嘔 吐，全身倦怠感が強くなり 9 月 27 日来院。来院時 FBS 495, 尿中細菌多数。昨年も同様な事態で敗 血症を来して治療に苦労した事があったので直ち に入院。

現 症: 皮虑枯燥し顔色不良。舌は紅滑一部地 図状で乾いている。脈浮数軟。腹部軟弱で抵抗, 圧痛, 悸などはない。往来寒熱 $(+)$ 。嘔気 $(-)$ 。 渴 $(+)$ 。口苦 $(+)$ 。頻尿。

経 過(図 3)：輸液とインスリン持続注射, 抗 生剂 CMNX, 内服は当初から小柴胡去半夏加括 樓根湯で開始した。FBSや炎症反応の改善には 1 週間以上かかったが，自覚症状は 4,5 日で消 失。本例では抗生剂は有効であったと思われるが （尿培養では E. coli が検出。感受性 $(+)$ )，本例 が通常の急性婜盂腎炎より治療抵抗性であること を考光れば，本方剤も大きく笴与していると思わ

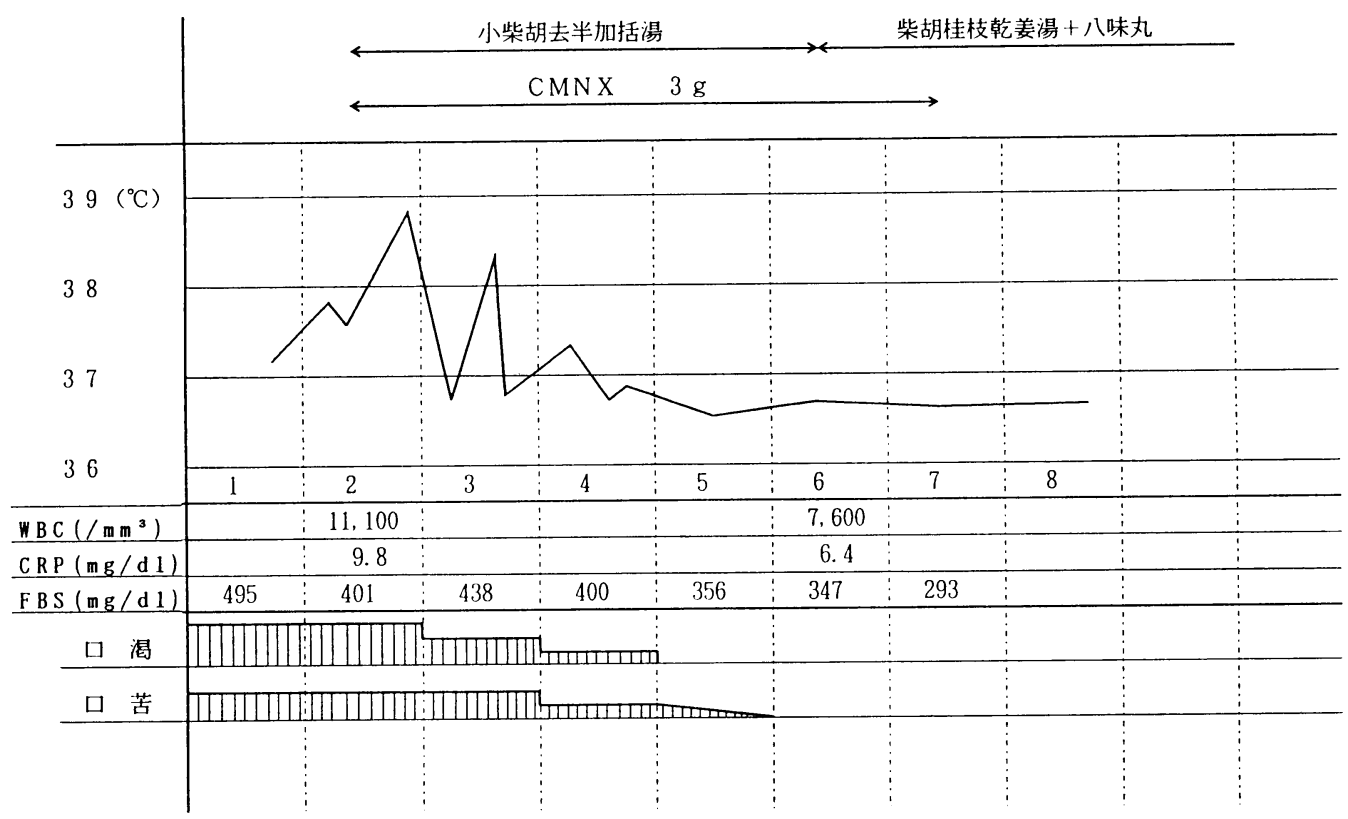


れる。

以上 3 例とも本方剂の有効性は認めてよいだろ う。その効果発現は比較的速やかである。他覚的 所見の改善は自覚症状の改善に比しかなり遅れ る。

本方剤のポイントは渴にある。軽度の渴なら小 柴胡湯でよい。本症例のように重篤な急性感染で 小柴胡湯証が出現した場合, 胸脇で気の疎通が阻 害され，血熱の影響もあって津液の流通障害で渴 がでる。本症例のように, 多量の飲水をする程で はないがその口乾は非常に苦痛なのが特徵であ る。

\section{考 察}

少陽病は多くの感染症が最も長く滞在する病位 であり，その中でも小柴胡湯はとりわ流応範囲 が㕕い。症例 2 のような胆道系の感染症は時とし て重症化しやすいが，その時でも小柴胡湯は著効 を示すことがある1。柴胡サポニンや黄芩のフラ ボノイド色素には, 強い抗炎症作用, 抗アレルギ 一作用, 抗菌作用がある。半夏, 生姜は痰飲を消 乙和胃, 制吐に, 人参, 甘草, 大東は脾を補い扶 正去邪を助ける。

前記小柴胡湯の条文に於て, 往来寒熱から心煩 喜嘔までが定証であり或以下は兼証である，とい らことで先哲の見解は一致している。方後の加減 法については，後人が書き加えたものであるとい うことでほぼ共通しているが，それを採用するか 否かは意見が分かれている。尾台榕堂2)，中西深 斎 $^{3)}$, 山田正珍4), 浅田宗伯 ${ }^{5)}$ らは, 後人の加ふる 所従うべからず，として無視している。

宇津木昆台6), 内藤希哲 ${ }^{7}$ (場合によっては考 慮すべしとしている。代表的な二人の見解を紹介 する。尾台榕堂は「或以下の症は本方の兼治する 所なり。故に本論に或はと言ひて若くはと言わ ず。若くはと言う時は即ち必ず加味あり。後人或 は若と義異るあることを知らず妄りに加減の法を 作る」として加減法を否定している。

一方，宇津木昆台は「或より以下は，病者の宿 によりて，同じ小柴胡湯の証を病むにも少しずつ の兼証あり，その兼証でも本症につれて全く波及
したる者ならば加減するには及ばざれども，元来 にその兼証の癖あるか又は元来の癖にあらざれど も, 本方の症を病むにつけてその兼証の迫りのあ る者は，よくよく八條目を推し究て加減をなすべ し，漫に加減して本方の主意を取りはずす事なか れ。或はと云うは不定の辞にして有無一定し難 し。若と云うは或よりは少ししっかりとして此如 の兼証をあらわすときはと云処に，何の加減をす ると。或の字を受てみるべし。」して，みだり に加減をすべきではないが，その兼証が急迫して いるときは加減も考虑すべしと言っている。

重篤な感染症では, 強力な外邪のため胸や脇に 父血が逼迫して水も滞り, 渴を生じる。この渴が 著しい場合は小柴胡湯で対応しきれず，小柴胡去 半夏加括樓根湯という加減方が適当であった。本 症例の経験では, 方後の加減法は後人の作ったも のではあるが，一概に捨て去らないで利用すべき 価值があると思われる。

金匱要略瘧病篇に柴胡去半夏加括樓湯がある。 「治瘧病渴者, 又治労瘧。」ここでは人参を増量し ていないのが小柴胡湯加減法と異なる。柴胡去半 夏加括樓湯は比較的慢性化した労瘧のような状態 で，津液が枯れてきたのを括樓根で潤燥生津止渴 する。小柴胡去半夏加括樓根湯は, 宇津木昆台に よれば「津液の乾燥するより心胸間の血液めぐら ず, 気の立のび兼るより発する渴が柴胡去半夏加 括樓溸の渴。本方では，水は胸に留りながらも， 其水，血を滋潤すること能わずしてなす渴なり。 人参のかかる所の渴は, 血気凝結して水と和合せ ず滋潤を失てより発する渴なり, 血の凝りなく津 液の竭て渴する者は人参の証にあらず。」このよ うに, 人参を増量するか否かで二つの方剂の病態 に微妙な差違がある。

\section{おわりに}

比較的重篤な急性感染症で小柴胡湯証を呈しな がらも渴の強い場合があり, その時小柴胡去半夏 加括樓根湯が有効であることを示した。小柴胡湯 条支方後の加減法に対する評価については, 先人 達の見解を引用しながら，有益な場合があること を述べた。 
金匱要略の柴胡去半夏加括樓湯との異同につい て若干の考察を加光た。

本論文の要旨は第44回日本東洋医学会学術総会にお いて発表した。

\section{文 献}

1）岩崎 勲：真菌血症をきたし漢方薬が奏功したレ イノ一病の一例, 綜合臨牀, 41(1)，185, 1992

2 ）尾台榕堂，類聚方広義，近世漠方医学書集成， 57 , 139, 1980
3 ) 中西深斎, 傷寒論弁正, 近世漢方医学書集成, 35, 183,1981

4 ）山田正珍, 傷寒論集成, 近世漢方医学書集成, 74, 391, 1983

5 ) 浅田宗伯, 傷寒論識, 近世漢方医学書集成, 97, 224, 1982

6 ）宇津木昆台，古訓医伝，近世漢方医学書集成，25, 280, 1980

7 ) 内藤希哲, 傷寒雑病論類綼, 近世漢方医学書集成, $71,246,1983$

（1993年 9 月29日受領）

\section{Abstract \\ Clinical Experience of Shosaiko-kyohange-kakarokon-to to Acute Infectious Diseases}

Isao IWASAKI

M. D., Practitioner, Hokkaido

I studied three cases of acute infectious disease which responded to Sho-saiko-kyohange-ka-karokon-to. One had acute pneumonia and AGML, one had septicemia complicated with cholangitis, and the other had hydronephrosis complicated with acute nephropyelitis. All these cases presented signs for which Sho-saiko-to is indicated, but the patients had severe thirst. I also used antibiotics and fluid therapy, but I believe the main effects were achieved by this herbal formulation, which was prepared by removing pinellia tuber from sho-saiko-to, increasing Ginseng radix 1.5 fold, and adding trichosanthes root. In a text on Sho-saiko-to, I studied early researchers' views on this formulation. I also studied the differences between Sho-saiko-kyohange-ka-karokon-to and Saiko-kyo-hange-ka-karo-to in the Jin kui yao lue and found that there are some differences in features of the disease. 